\title{
ENTRE O SUJEITO E O DISCURSO, O PROCESSO IDENTITÁRIO DA CHINA
}

\section{ENTRE EL SUJEITO Y EL DISCURSO, EL PROCESO IDENTITARIO DE CHINA}

\author{
Vania Maria Lescano Guerra* \\ Elza Mieko Koba Perles**
}

Resumo: Este artigo vem problematizar o discurso do jornal Folha de S. Paulo, acerca da China, país em franco desenvolvimento e sede das Olimpíadas de 2008, e examinar as relações de poder que determinam a imagem identitária daquele país perante os brasileiros. Tomando como acontecimento discursivo as Olimpíadas de Pequim, por ser um evento de relevância internacional, partimos da hipótese de pesquisa de que o evento esportivo fez emergir um novo discurso acerca desse país nos órgãos midiáticos. Da perspectiva foucaultiana, o acontecimento do discurso deve ser entendido pelo princípio de sua regularidade, de modo que para analisar o discurso é preciso pensar o acontecimento, as séries, a regularidade e as condições de possibilidade. O discurso midiático reorganiza os relatos de supostas verdades sobre a realidade, de modo que as relações de poder não se mostram como tal, são travestidas de "retrato fiel da realidade", de verdade única dos fatos, veiculadas como se não existissem outras vozes, outras verdades (NAVARRO-BARBOSA, 2003).

Palavras-chave: Identidade. China. Discurso. Acontecimento.

Resumen: Este artículo viene problematizar el discurso del periódico Folha de S. Paulo, sobre China, un país en franco desarrollo y la sede de los Juegos Olímpicos de 2008, y examinar las relaciones de poder que determinan la imagen identitaria del país adelante a los brasileños. Teniendo como acontecimiento discursivo los Juegos Olímpicos de Pequim, por ser un evento de relevancia internacional, suponemos la hipótesis de estudio que el evento deportivo hizo surgir un nuevo discurso

\footnotetext{
*Vania Maria Lescano Guerra, doutora em Linguística e Língua Portuguesa pela Universidade Estadual Paulista Júlio de Mesquita Filho (2002), Pós-doutorado sobre Identidade, Discurso e Cultura no IEL, UNICAMP, no Programa de Linguística Aplicada. Professora associada da Universidade Federal de Mato Grosso do Sul e pesquisadora do CNPq. Email: vguerra1@terra.com.br

** Mestre em Estudos Linguísticos do Programa de Pós-graduação em Letras da Universidade Federal de Mato Grosso do Sul, Câmpus de Três Lagoas. Email: elzakoba@hotmail.com
} 
sobre China, en los medios de comunicación social. De acuerdo con la perspectiva foucaultiana, el acontecimiento discursivo debe ser entendido por el principio de su regularidad, de modo que para analizar el discurso tenemos que pensar el acontecimiento, la serie, la regularidad y las condiciones de posibilidad. El discurso de los medios de comunicación reorganiza los informes de supuestas verdades acerca de la realidad, de modo que las relaciones de poder son travestidas de fiel retrato de la realidad, en verdad única de los fatos, como si no hubieron otras voces, otras verdades (NAVARRO-BARBOSA, 2003).

Palabras-clave: Identidad. China. Discurso. Acontecimiento.

\section{PRELIMINARES}

A linguagem preexiste à entrada de cada sujeito num momento de seu desenvolvimento mental. [...] Também o sujeito se pode parecer servo da linguagem, o é ainda mais de um discurso em cujo movimento universal seu lugar já está inscrito em seu nascimento, nem que seja sob a forma de seu nome próprio. $(\text { LACAN })^{1}$

A sociedade contemporânea se configura como a sociedade do conhecimento, na qual a informação, tanto no nível local quanto global, constitui-se em fonte de saber que confere poder. Nessa perspectiva a mídia exerce papel fundamental na configuração desse saber/poder, visto que ela é uma importante instância de produção de informação que circula no meio social. Em função do papel que exerce na atualidade, o discurso midiático tem sido objeto de muitos estudos da perspectiva da Análise do Discurso de linha francesa $(\mathrm{AD})$, que procura mostrar a constituição do discurso e explicar os mecanismos que embasam a produção de sentido.

I Ver Lacan (1988, p. 498)
Os órgãos midiáticos, sobretudo os jornais, são formadores de opinião e exercem influência na formação identitária dos mais variados segmentos sociais, posto que a representação identitária que os jornais veiculam, seja subliminarmente, seja explicitamente, é constitutiva de nosso imaginário social.

Este trabalho ${ }^{2}$ pretende problematizaro discurso do jornal Folha de S. Paulo, doravante FSP, acerca da China, país em franco desenvolvimento e sede das Olimpíadas de 2008, e examinar as relações de poder que determinam a imagem identitária daquele país frente aos brasileiros. Tomando como acontecimento discursivo as Olimpíadas de Pequim, por ser um evento de relevância internacional, partimos da hipótese de pesquisa de que o evento esportivo fez emergir um novo discurso acerca da China nos órgãos midiáticos. Da perspectiva foucaultiana, o acontecimento do discurso deve ser entendido pelo princípio de sua regularidade, de modo que para analisar o discurso é preciso pensar o acontecimento, as séries, a regularidade e as condições de possibilidade.

2 Esta pesquisa se insere no Diretório do CNPq, do Grupo de Estudos "Vozes (in)fames: exclusão e resistência", sob a coordenação da Profa. Dra. Maria José Rodrigues Faria Coracini (IEL/UNICAMP). 
Para tanto analisamos dois excertos do discurso em questão à luz dos preceitos teóricos da $\mathrm{AD}$, a partir dos trabalhos de Foucault (2001, 2008a, 2008b e 2009), bem como das teorias do discurso midiático trazidos por Charaudeau (2009). O primeiro excerto foi retirado da reportagem "Made in China”, publicado em 09 de agosto de 2008 e o segundo, da entrevista concedida pela antropóloga Susan Brownell, publicada em o6 de julho de 2008.

A escolha temática deste trabalho se deve à importância que a China alcançou no cenário mundial, tornando-se em 2010 a segunda economia do mundo, com perspectivas de superar os Estados Unidos nos próximos vinte anos (TREVISAN, 2006). Quanto à opção pelo discurso midiático, o estudo acerca da China decorre da importância das mídias na sociedade contemporânea, dada sua penetração nas mais diferentes classes sociais, bem como por ser responsável, em certa medida, pela construção do imaginário social, pois cria formas simbólicas que representam o mundo real que são cristalizados e incorporados pela sociedade - segundo Gregolin (2003), a mídia se configura pela construção da história do tempo presente. Devemos considerar ainda que toda informação que possuímos sobre a China nos chega por meio da mídia, sobretudo jornalística e televisiva, em virtude do isolamento por que passou o país asiático durante décadas.

Buscamos neste artigo desvelar a construção dos efeitos de sentido do discurso midiático e buscar os efeitos de verdade que emergem da opacidade do discurso travestida pela aparente neutralidade $\mathrm{e}$ transparência e, desse modo, mostrar a configuração discursiva da representação iden- titária que a FSP constrói acerca da China. Essa representação é constituída nos fios do discurso, num entrelaçamento com as teias da memória e da história, de modo que estudar a identidade chinesa pressupõe o conhecimento da história recente e antiga da China, bem como de toda a complexidade que envolve esse país. Pressupõe ainda relacionar o discurso com as teias da memória e as representações identitárias consolidadas no imaginário social ocidental a respeito desse país emergente.

Tanto para Fish (1992) quanto para Coracini (2007), o poder cria regras de conduta que acabam abafando a multiplicidade de pontos de vista, responsáveis pelas contradições e pelos conflitos, capazes de provocar as mudanças interna e externa necessárias. Consideramos que as visões de imaginário que perpassam os textos de Fish e Coracini surgem como diretrizes de nossa interpretação. A visão discursiva de Coracini traz o imaginário ligado a representações socialmente construídas e transmitidas, isto é, sempre que lemos estamos interpretando, construindo sentido a partir do que somos, do momento sócio-histórico que nos constitui como sujeitos.

\section{O PROCESSO DISCURSIVO E O ENGENDRAMENTO DO PODER}

O discurso, na perspectiva teórica da $\mathrm{AD}$, é tomado como práticas sociais que se constituem sócio-historicamente entre os sujeitos, cujo funcionamento engendra a confluência entre a língua, o sujeito e a memória. (GREGOLIN, 2003, 2007) Assim, estudar o discurso pressupõe analisar a produção de sentido desse discurso a partir da 
materialidade linguística em sua relação com o sujeito enunciador, com a história e a memória, que (re)atualiza o dizer. Desse modo, as palavras (re)significam numa constante inter-relação com a história e a memória na forma de interdiscursos, de outros já ditos, fora, em outro lugar. Vale ressaltar, portanto, que as palavras não são neutras, tampouco transparentes, ao contrário, denunciam posições ideológicas que emergem das relações com os outros discursos, com o interdiscurso. Além disso, o discurso, na perspectiva foucaultiana, não pode ser estudado fora das relações de poder.

De acordo com Foucault (1990), discurso e poder se inter-relacionam, de modo que as relações de poder permeiam a produção do discurso. Para o filósofo, o poder surge como questão metodológica. $\mathrm{O}$ poder não se localiza em instituições como o Estado, não é algo que um indivíduo cede ao soberano, o poder é, antes, uma relação de forças e como tal está em todas as partes, ou seja, o poder atravessa todas as relações pessoais e sociais. As incursões foucaultianas nos estudos do discurso são evidenciadas em várias de suas obras, sobretudo em "Arqueologia do saber" (2008a), "A ordem do discurso" (2008b) e "Microfísica do poder" (2009). A grande contribuição de Foucault diz respeito ao sujeito e suas relações com o poder, saber e a verdade, bem como com os deslocamentos e as formas como os discursos se constituem ao longo do tempo. Nessa perspectiva, configuram-se as noções de ruptura, descontinuidade, dispersão, de modo que o discurso passa a ser estudado em seu acontecimento discursivo, em sua historicidade.
A história, na perspectiva foucaultiana, não deve ser vista em sua linearidade, na sucessão de fatos históricos, deve antes ser pensada em sua descontinuidade, na ruptura, em que emergem as relações de poder. Nesse aspecto, tornam-se relevantes as noções de arquivo e genealogia, bases dos preceitos teórico-metodológicos denominados arqueogenealogia, que fundamentam esta pesquisa. Foucault (2008a) chama de arquivo a soma de todos os discursos possíveis, sem estabelecer nenhuma hierarquia de valores, apenas buscando as regularidades do discurso: é sobre esse arquivo que a arqueologia deve incidir. O método arqueológico investiga a natureza do poder na sociedade a partir dos discursos produzidos na sociedade numa dada época. Para o filósofo, interessam os discursos sobre a psiquiatria, a medicina e o direito, desse modo ele investiga a natureza desses saberes, rejeitando qualquer tentativa de unificação da memória coletiva, da linearidade histórica. Ao contrário, busca na descontinuidade e na dispersão os fundamentos de sua pesquisa.

O conceito de genealogia apoia-se em Nietzsche, que estabelece a história do presente nos domínios dos saberes. O método genealógico postula a relação do saber com o poder, considerados em uma relação intrínseca. Assim, esta pesquisa busca, nos arquivos do discurso midiático sobre a China, as relações de poder que possibilitam o aparecimento desse discurso. Foucault dedicou inúmeros estudos às relações de poder que regem as relações sociais, sobretudo nas obras já citadas, bem como em "Vigiar e punir" (2001). Já em seus livros intitulados "Arqueologia do saber" (2008a) e "A ordem do discurso" (2008b), o historiador investiga como os saberes foram se constituindo 
e suas condições de aparecimento. Nessa fase chamada arqueológica, ele apresenta o método arqueológico no qual o analista, qual um arqueólogo, "escava" os enunciados a fim de investigar seu funcionamento e compreender a formação discursiva que possibilitou seu aparecimento.

Em "Arqueologia do saber" (2008a), Foucault apresenta também a noção de Formação Discursiva, tão cara para a $\mathrm{AD}$ e que influenciou as pesquisas de Pêcheux. O conceito de FD possibilitou ao filósofo investigar como o saber se constitui a partir das práticas discursivas em determinada época. Tomando o enunciado como acontecimento discursivo, para Foucault (2008a, p. 30) interessa "como apareceu um determinado enunciado e não outro em seu lugar", desse modo o autor investiga o funcionamento do discurso no âmbito das formações discursivas, trazendo à tona o surgimento do saber psiquiátrico sobre a loucura. As formas de exercício do poder são ressaltadas em "Vigiar e punir" (2001) e "Microfísica do poder" (2009). Em sua vasta obra, Foucault estudou as formas de exercício do poder ao longo da história, cujas práticas punitivas do corpo foram se transformando em práticas disciplinares, em sistemas de controle, poder e exclusão. Para ele, por meio do poder disciplinador é possível explicar o funcionamento do poder sobre o indivíduo na sociedade moderna. As práticas disciplinares, segundo o filósofo, conduzem à sociedade disciplinar, e o poder disciplinador é também exercido pela escola, igreja, quartel, hospital, entre outros. Nessa perspectiva, a disciplina utilizada no sistema carcerário também é uma das formas de adestrar o indivíduo e torná-lo produtivo (GREGOLIN, 2003, p. 101), do mesmo modo, os sistemas de segurança, com câmeras de vídeo, também representam o poder disciplinador: assim, toda a sociedade é submetida a ele. De certa forma, a mídia jornalística também exerce esse tipo de poder disciplinar, pois as condutas consideradas irregulares costumam estampar as manchetes de jornais.

$\mathrm{O}$ poder não se manifesta, portanto, de forma centralizada e hierárquica, na figura do Estado, ele se espalha e se estende por toda a sociedade, manifestando-se em micropoderes (FOUCAULT, 2001), por meio das relações de luta e jogos de força entre os grupos sociais. Tal embate de relações de força ocorre no âmbito do saber, de modo que poder e saber se imbricam. Gregolin (2003, p. 100) ressalta que a disciplina gera saber e este por sua vez gera poder, de modo que poder e saber se relacionam intrinsecamente. E no âmbito do discurso midiático, o poder das mídias se concentra, fundamentalmente, nas práticas discursivas relacionadas ao regime de verdade. Conforme já dissemos, a ilusão da unicidade do discurso midiático, bem como sua aparente objetividade, criam efeitos de verdade. Ao analista do discurso cabe dissecar a construção desse discurso e revelar os efeitos de sentido possíveis, circunscritos nas formações discursivas, nas quais o sujeito enunciador se inscreve, bem como a vontade de verdade desse discurso.

Para Foucault (2008b p. 9), em nossa sociedade a produção do discurso passa por processos de exclusão, de interdição, de modo que "não se tem o direito de dizer tudo, não se pode falar de tudo em qualquer circunstância, que qualquer um, enfim, não pode falar qualquer coisa". O discurso sobre a sexualidade e o discurso político são, para o filósofo, lugares privilegiados onde o poder se manifesta. Foucault (2008b, p. 19) 
nos ensina, ainda, que não existe a verdade, mas a vontade de verdade, considerada, junto com a palavra proibida e a segregação da loucura, os três grandes sistemas de exclusão que atingem o discurso. Segundo o filósofo, qualquer um não pode falar qualquer coisa, o discurso se encontra inserido em uma "ordem do discurso", do qual fazem parte esses sistemas de exclusão. A vontade de verdade também se configura como uma construção sócio-histórica na confluência com o poder. A verdade é construída em cada época, de acordo com as forças de poder que as regem em cada período histórico.

Dos três sistemas de exclusão, é da vontade de verdade que menos se fala, pois ela se nos apresenta mascarada pela própria verdade: apresenta-se aos nossos olhos como verdade única e universal. A vontade de verdade se configura como sistema de exclusão, pois ela exclui todas as outras verdades que a ela se contrapõem. Concernente ao discurso midiático, a vontade de verdade é perpassada pelos interesses econômicos e mercadológicos, visto que a sociedade pós-moderna, de acordo com Jameson (2001), é constituída sob a égide do capitalismo tardio e da globalização da economia. Assim, ela constrói sua verdade a partir das relações de poder do capital, e a mídia, como toda a sociedade, também é regida pelas mesmas relações de poder. Considerando que o discurso verdadeiro é construído historicamente pelas relações de poder em cada época, um discurso considerado verdadeiro em determinado período pode não o ser em outro, ou na mesma época, mas em sociedade com valores culturais diferentes. Assim, a verdade historicamente construída no Ocidente pode não se apresentar como tal no Oriente, ainda que este seja afetado pela globalização e pelo domínio cultural norte-americano. O discurso da Folha de S. Paulo, concernente à abertura dos Jogos Olímpicos de Pequim, parece traduzir a vontade de verdade do capitalismo Ocidental, cujos valores não são exatamente os mesmos do comunismo chinês, ainda que a abertura econômica tenha inserido a China no mercado globalizado.

Charaudeau (2009, p. 48) assevera que a verdade, para as sociedades ocidentais, pré-existe à sua manifestação, no entanto essa premissa se encerra na medida em que o ser humano é o agente e ao mesmo tempo beneficiário da verdade; sendo assim, ela é marcada pela contradição, pois se a verdade é exterior ao ser humano, ao mesmo tempo só pode atingi-lo por meio de seu sistema de crenças e valores. Com efeito, Charaudeau (2009, p. 49) define valor de verdade e efeito de verdade no discurso midiático: o valor de verdade é expresso por meio de construções explicativas de caráter científico exterior ao ser humano, que se define como "técnicas de saber dizer, de saber comentar o mundo"; já o efeito de verdade está ligado ao crer verdadeiro, é, pois, subjetivo, sendo que cada sujeito confere um efeito de verdade de acordo com a relação que estabelece com o mundo. O discurso midiático não busca a verdade em si, mas a credibilidade, posto que a verdade é uma construção discursiva.

Na perspectiva de Charaudeau, torna-se mais apropriado falar em veracidade da notícia do que em verdade veiculada pela notícia. Já na perspectiva foucaultiana, a verdade não existe fora do poder, ela é construída no/pelo poder. Para a $\mathrm{AD}$, importa mais a constituição do discurso midiático, ou seja, a explicação de seus mecanismos e de suas estratégias discursivas que pro- 
duzem os efeitos de sentido interpretados pelo leitor. Desse modo, ao adotarmos a perspectiva foucaultiana nesta pesquisa, importa-nos o desvelamento das relações de poder que determinam a vontade de verdade do discurso midiático, considerando a intersecção entre a língua, o discurso e a história, bem como a memória discursiva que permite os deslocamentos de sentido decorrentes de usos linguísticos feitos pela mídia, tal como ocorre no título da reportagem "Made in China", sobre a abertura das Olimpíadas, veiculada pela FSP.

Devemos considerar que esse título inscreve no discurso jornalístico a memória do discurso econômico. A expressão "made in" significa "feito em" e remete à produção industrial destinada à exportação. Afora isso, devemos considerar o contexto amplo que inseria a China como um dos principais responsáveis pela indústria da falsificação de produtos industriais de baixa qualidade. Portanto, esse título, referindo-se à abertura dos Jogos Olímpicos de Pequim, parece conferir ao evento o mesmo caráter de falsificação. Desse modo, a memória discursiva (res)significa o dizer, conferindo à expressão-título um sentido outro que só é recuperado pelo interdiscurso, pelos já-ditos que cristalizaram uma representação identitária da China como o "paraíso da pirataria".

Vale dizer que, na Análise de Discurso, o texto não é visto como uma unidade fechada, com começo, meio e fim. Pelo contrário, ele é estudado a partir de sua relação com outros textos (existentes, possíveis ou imaginários), com as condições de produção (os sujeitos e a situação), com a exterioridade constitutiva (o interdiscurso: a memória do dizer), o que caracteriza sua incompletude (ORLANDI, 1996, p. 54). E no que diz respeito às formações discursivas (FD), Pêcheux (2009, p. 162) diz que o propósito de toda formação discursiva é dissimular, mascarar na evidência e transparência do sentido que nela se forma, a objetividade material contraditória do interdiscurso. Objetividade material essa que reside no fato de que algo fala sempre antes, em outro lugar e independentemente, a partir do que pode e deve ser dito em cada discurso (FD). Nessa ótica, o interdiscurso é a relação de um discurso com outros discursos, constitui os outros dizeres, o já-dito. Apoia-se na noção de pré-construído que, por sua vez, refere-se ao "sempre-já-aí" da interpelação ideológica que impõe a realidade e seu efeito de sentido sob a forma da universalidade. (cf. PÊCHEUX, 2009, p. 164). Graças ao interdiscurso, o sujeito pode sustentar o seu dizer por meio das filiações de sentido presentes no já-dito.

ARQUIVO E INTERPRETAÇÃO: ASPECTOS HISTÓRICOS E SOCIAIS

Tanto para Fish (1992) quanto para Coracini (2007), o poder cria regras de conduta que acabam abafando a multiplicidade de pontos de vista, responsáveis pelas contradições e pelos conflitos, capazes de provocar as mudanças interna e externa necessárias. Consideramos que as visões de imaginário que perpassam os textos de Fish e Coracini surgem como diretrizes de nossa interpretação. A visão discursiva de Coracini traz o imaginário ligado a representações socialmente construídas e transmitidas, isto é, sempre que lemos estamos interpretando, construindo sentido a partir do que somos, do momento sócio-histórico 
que nos constitui como sujeitos (GUERRA, 2010).

Logo após o término dos Jogos de Pequim, em outubro de 2008 , o mundo inteiro se viu assolado pela maior crise econômica depois de 1929 (CARDOTE, 2009), cujo epicentro ocorreu nos Estados Unidos. Enquanto isso, a China, embora afetada pela crise internacional, apresentou um crescimento de 9,6\%, em 2008 , e $8,7 \%$, em 2009 (BBC Brasil, 2010). Tais números mostram o país asiático como um dos responsáveis pela recuperação econômica mundial, ampliando a relevância da China como potência internacional, despertando cada vez mais o interesse dos países ocidentais a respeito desse país que se abriu para o capitalismo, mas conduz com rigor a estrutura política do Partido Comunista.

Durante a realização das Olimpíadas de Pequim o mundo todo esteve conectado com o País do Meio, emissoras de televisão e jornais do mundo todo enviaram correspondentes ao país para acompanhar e transmitir os Jogos. A cerimônia de abertura, que aconteceu no dia oito de agosto de 2008, às 20h, horário de Pequim, foi assistida por aproximadamente 4 bilhões de pessoas em todo o mundo, de acordo com os organizadores do evento. Diante do objetivo deste trabalho, qual seja encontrar, na materialidade linguística, na opacidade da língua, nos fios que tecem o discurso jornalístico da mídia brasileira, indícios da identidade chinesa, tomando como acontecimento discursivo as Olimpíadas de Pequim, consideramos necessária a compreensão do conceito de arquivo, formulado por Foucault (2008a). Para o filósofo a noção de arquivo não se refere à "soma de todos os textos que uma cultura guardou em seu poder, como documento de seu próprio passado, ou como testemunho de sua identidade mantida" (2008a p. 146). $\mathrm{O}$ arquivo é antes

o que faz com que tantas coisas ditas por tantos homens, há tantos milênios, não tenham surgido apenas segundo as leis do pensamento, ou apenas segundo o jogo das circunstâncias, que não sejam simplesmente a sinalização, no nível das performances verbais, do que se pôde desenrolar na ordem do espírito ou na ordem das coisas; mas que tenham aparecido graças a todo um jogo de relações que caracterizam particularmente o nível discursivo. (FOUCAULT, 2008a, p. 146)

A noção de arquivo, conforme proposta por Foucault, refere-se, pois, à análise de um conjunto de enunciados produzidos segundo um sistema de enunciabilidade, segundo leis que regem seu aparecimento. Para Coracini (2007, p. 16), o arquivo é "aquilo que justifica, sem que se saiba sua razão imediata, o que pode ser dito num dado sistema de discursividade: é, enfim, o que dá sentido ao que é dito", desse modo, $\mathrm{o}$ arquivo se relaciona com a memória, que (re)atualiza os dizeres. A autora assevera ainda que a noção foucaultiana de arquivo sofre a ação das relações de poder, visto que é responsável pela materialização das práticas discursivas. De acordo com Foucault (2009, p. 8), o poder é produtivo e não apenas repressivo, ele produz coisas, produz o saber, o discurso. O discurso por sua vez é "ao mesmo tempo instrumento e efeito de poder" (CORACINI, 2007, p.17); se o discur- 
so é o lugar onde se exerce o poder, é também o lugar de resistência, visto que, para Foucault, não existe poder sem resistência. Ou seja, o sujeito resiste ao poder, sendo o discurso instrumento e efeito do poder e o sujeito uma constituição discursiva, o sujeito resiste ao poder que o constitui.

Consideramos que a mídia jornalística se configura como uma instância de poder que produz um saber; o poder de circulação e a abrangência do discurso midiático conferem à instância midiática o status de "quarto poder", segundo Charaudeau (2009). O discurso midiático reorganiza os relatos de supostas verdades sobre a realidade, de modo que as relações de poder não se mostram como tal, são travestidas de retrato fiel da realidade, de verdade única dos fatos, veiculadas como se não existissem outras vozes, outras verdades. Pode-se dizer que a memória social, que outrora se encontrava nas relações sociais e culturais dos indivíduos, agora se encontra nos arquivos da mídia (NAVARRO-BARBOSA, 2003, p. 116), tornando-se dispositivo identitário e produtor de subjetividades. Para Coracini (2007, p. 60), a identidade seja nacional, seja individual é construída socialmente por quem tem o poder, por quem, legitimamente, tem o poder de dizer verdades. Assim, procuramos "escavar", nos arquivos do discurso midiático, indícios da constituição identitária de um país controverso e importante como a China.

O MOVIMENTO IDENTITÁRIO DA ChINA NO DISCURSO DA FSP: DESLOCAMENTOS

Em E1, encontramos a referência aos protestos que antecederam a Olimpíada, marcando o evento como eminentemente político.

E1 - O desfile das 204 delegações de atletas também fez lembrar que a festa era política. Aliados da China no cenário internacional, Paquistão, Cuba e Coreia do Norte foram os mais aplaudidos - depois, claro, da anfitriã. As passagens de EUA, Japão e França mereceram murmúrios e aplausos polidos. [...] Os discursos, embora breves, também tiveram pitadas políticas. Presidente do COI (Comitê Olímpico Internacional), o belga Jacques Rogge disse que os Jogos "são o encontro de 204 nações, independentemente de origens étnicas, sexo, religião ou sistema político". Comandante do comitê organizador de Pequim, Liu Qi falou em "aprofundamento do entendimento mútuo". Isso diante de jovens vestidos com trajes das 56 minorias étnicas chinesas, pintando um retrato de harmonia que os protestos de tibetanos e muçulmanos uigures insistem em desmentir. ${ }^{3}$

As marcas formais indicam uma afirmação do caráter político do evento com a utilização do operador argumentativo "também" em "O desfile das 204 delegações de atletas também fez lembrar que a festa era política", ou seja, para a FSP, a cerimônia, de modo geral, teve viés político, apesar do esforço empreendido pelo governo chinês em mostrar apenas a festa colorida. Para o jornal, os aplausos aos aliados políticos da China e os "murmúrios e aplausos contidos"

3 Grifos nossos. 
aos não aliados são indícios da conotação política do evento, sobretudo se considerarmos que tais aliados são países fechados que vivem sob o regime socialista e sofrem sanções econômicas impostas pela ONU. Além disso, o operador argumentativo "também" vem reativar os acontecimentos que antecederam os Jogos, ou seja, os protestos contra a China em razão dos confrontos no Tibet, de modo que o discurso da FSP aqui se encontra inscrito na FD política atravessada pela FD dos direitos humanos.

Durante o desfile das delegações, segundo o jornal, houve o silenciamento dos países não aliados da China, ao mencionar "os aliados da China no cenário internacional Paquistão, Cuba e Coreia do Norte foram os mais aplaudidos"; aqui, são silenciados também todos os outros países que não o são, dentre os quais estão Estados Unidos, Japão e França, que, segundo o jornal, "mereceram murmúrios e aplausos polidos". Ressaltamos que os referidos países são tradicionais opositores do regime comunista chinês, embora se apresentem como importantes parceiros comerciais. De acordo com Foucault (2008b), há um dispositivo de interdição, de silenciamento, no processo de produção de sentido que nos faz entender a dimensão do não dito. No desvelamento das relações de poder que determinam a vontade de verdade do discurso midiático, o silenciamento desses países, sobretudo dos Estados Unidos, revela um confronto velado entre os países socialistas, aliados da China, e as potências capitalistas ocidentais.

Para Bhabha (2007), o Japão deve ser considerado como pertencente ao bloco capitalista ocidental, embora situado na Ásia oriental. Temos então um confronto entre as mais importantes nações do mundo e a mais nova superpotência mundial que ora emerge; assim, o silenciamento das potências ocidentais pode ser interpretado como uma forma de resistência ao domínio do imperialismo ocidental. Também são interditadas pelo governo chinês, segundo o jornal, as vozes das minorias étnicas, conforme observamos em E1, na passagem "comandante falou em 'entendimento mútuo". As palavras da autoridade chinesa referem-se aos conflitos e protestos envolvendo a China, testemunhados pelo mundo, nos meses que antecederam o evento esportivo. Ao dizer algo, automaticamente se interdita o que não é dito, assim, a expressão "entendimento mútuo" silencia os conflitos, de certa forma, censura os protestos e os direitos exigidos pelas etnias subordinadas a Pequim, excluindo esses segmentos da sociedade chinesa. Frente à assertiva do jornal impresso de que "Isso [ocorreu] diante de jovens vestidos com trajes das 56 minorias étnicas chinesas, pintando um retrato de harmonia que os protestos de tibetanos e muçulmanos uigures insistem em desmentir", a FSP vem conferir às palavras do presidente do comitê organizador uma "vontade de verdade": a versão chinesa que confere apenas aos chineses o status de verdade vem implicar uma interdição da outra versão dos fatos aos olhos do mundo (FOUCAULT, 2008b).

Aqui, o silenciamento entre os interlocutores ainda pode ser entendido como uma não linguagem que percorre o círculo da linguagem, temporalmente configurada, não se confundindo com o ato de se calar, que, à sua maneira, é um modo de fala. Sabe-se, entretanto, que o silêncio é também "a fala de um ausente" (FREUD, 1984, p.110). E é no intervalo, no silêncio que algo continua a ressoar, algo fecundo que subjaz o discurso midiático: 
exclusão, subalternidade, inferioridade. Além disso, a heterogeneidade mostrada marcada pela presença do discurso direto, demarcada pelas aspas, configura um distanciamento entre a voz enunciativa do jornal e a afirmação feita pela autoridade chinesa, de modo que o discurso direto isenta o sujeito enunciador da responsabilidade pelo efeito de sentido provocado por tais palavras; no entanto o uso do termo referencial "isso" parece mostrar o espanto do sujeito jornalista diante de uma afirmação julgada "mentirosa", acerca da autoridade chinesa. Tal espanto se acentua se considerarmos que o discurso foi proferido por uma autoridade, por um sujeito que tem o direito de dizê-lo, a partir de uma fala que está na ordem do discurso.

De acordo com Foucault (2008b, p. 37), a produção do discurso é, ao mesmo tempo, controlada e selecionada, passando por procedimentos de exclusão, ou seja, "não se tem o direito de dizer tudo, não se pode falar de tudo em qualquer circunstância, qualquer um, enfim, não pode falar de qualquer coisa" para entrar na ordem do discurso é preciso satisfazer certas exigências, é preciso ser qualificado para fazê-lo. O Sr. Liu Oi está legitimado para enunciar tal discurso, ele fala do lugar de comandante do comitê organizador do evento, do lugar de autoridade que lhe permite proferir um discurso em nome do governo chinês.

Devemos considerar também que o discurso direto, ou o "discurso relatado", de acordo com Charaudeau (2009, p. 163), apoiado na operação de empréstimo, tem o objetivo de produzir autenticidade ao dito de origem. O sujeito jornal assume o posicionamento de autoridade ao relatar e mostrar ao público leitor que ele, sujeito, sabe o que diz, além de lhe conferir poder, o poder de dizer a verdade. Desse modo, podemos dizer que a utilização das palavras da autoridade chinesa, por meio do discurso relatado, confere ao sujeito FSP o status de enunciador da verdade.

Entendemos que o termo "isso", nesse caso uma anáfora indireta, remete não apenas às palavras de Lui Qi, mas ao fato de que o "aprofundamento do entendimento mútuo" silencia os conflitos étnicos e, sobretudo, as perseguições sofridas pelas minorias étnicas chinesas, ou seja, "isso" remete ao amplo contexto histórico-social que envolve essa questão tão conflituosa; além disso, a expressão "pintando um retrato de harmonia" mostra que essa harmonia é "forjada" pelo governo chinês. Assim, o discurso direto, retomado pelo termo referencial "isso", é utilizado pelo enunciador para contestar a autoridade chinesa por meio de suas próprias palavras.

A outra citação apresentada nesse excerto de E1 também demarcada por aspas confere ao enunciador a posição de autoridade, pois as palavras do presidente do COI confirmam o tom político do evento demonstrado pelo jornal, no decorrer da reportagem. Na passagem "independentemente de origens étnicas, sexo, religião ou sistema político", temos a emergência do interdiscurso (PÊCHEUX, 2009) que ativa a memória discursiva dos conflitos étnicos, religiosos e políticos, ocorridos no Tibet, além dos conflitos entre as Coreias, entre Israel e Palestina, entre Estrados Unidos e Iraque, bem como as desigualdades sexistas que, longe de terem sido resolvidas, devem, segundo "o belga Jacques Rogge”, ser substituídos pelo espírito olímpico, pois trata-se de um encontro de nações e não de confronto.

Convém explicar que a reunião das 205 nações, dos cinco continentes, em uma 
única cidade, torna os países participantes hóspedes e o país-sede hospedeiro, aquele que acolhe, que recebe o outro. Na noção de Derrida de hospitalidade, o hóspede deve ser acolhido incondicionalmente por aquele que hospeda, pois a lei da hospitalidade absoluta determina uma acolhida inquestionável; no entanto, o termo hospedar - hostis guarda em sua origem latina dois aspectos contraditórios: tanto indica hospitalidade, acolhimento, quanto hostilidade, de modo que o estrangeiro pode ser recebido como hóspede e como inimigo (2003, p. 41). Nas palavras da FSP, os aliados da China foram os mais aplaudidos "depois, claro, da anfitriã”, o que (res)significa que a China não hospeda todos os estrangeiros do mesmo modo, alguns ela acolhe e outros, hostiliza.

E2, o outro excerto analisado, foi extraído de uma entrevista da antropóloga americana Susan Brownell, radicada em Pequim, concedida ao jornalista Raul Juste Lores, cujo título é "Chineses ainda têm complexo de inferioridade". Na entrevista, a antropóloga traz as marcas identitárias dos chineses, conforme se vê em:

E2 - Os chineses têm uma estratégia de investir em esportes que vão se tornar olímpicos. E ganham medalha nesses chamados "esportes novos". Vários esportes que não eram olímpicos em 1984, hoje são dominados pelos atletas chineses. Eles também focaram em esportes sem tradição local, como o remo. O esporte é pouco praticado no mundo, então o nível internacional não é tão alto. É o oposto do que acontece com o futebol, onde o nível é altíssimo, então a China não consegue nada.
A China vai bem em badminton, tiro com arco, tênis de mesa, onde sempre foi forte, mas apenas ganhou na natação quando o doping não era tão controlado, depois nunca mais.[...] Muitos chineses ainda se veem com o preconceito ocidental do século 19. Julgam-se menores, mais fracos, desnutridos, pequenos, há um complexo de inferioridade. É uma ideologia desatualizada, que o resto do mundo já deixou para trás, mas que ainda deixa marcas no país.

Entendemos que o operador argumentativo "ainda", presente no título, remete à memória discursiva do período histórico em que a China foi subjugada pelas potências ocidentais, durante os séculos XIX e XX, em decorrência da Guerra do Ópio, quando a China se viu obrigada a ceder parte de seu território à possessão inglesa, francesa, alemã, russa, japonesa e americana. Ao mesmo tempo, a expressão atualiza o complexo de inferioridade atribuído aos chineses, trazendo-o para o tempo presente, num indício de que tal sentimento perdura até hoje. $\mathrm{O}$ que implica dizer que os chineses se encontram numa condição de subalternidade, embora o país se constitua como um dos principais polos econômicos do mundo. Para Bhabha (2007), todas as culturas não eurocêntricas se encontram na periferia, à margem, assim, a China continua sendo um país periférico, mesmo sendo a segunda maior economia do planeta, o que justifica o enunciado sobre o sentimento de inferioridade dos chineses.

A entrevista foi publicada pela FSP sem as perguntas formuladas pelo jornalista, assim, as palavras da antropóloga foram organizadas por temas e inscritas em rubricas. 
Sob a rubrica "Estratégia", o jornal traz o discurso de Brownell que parece atribui aos chineses uma imagem ardilosa, capaz de armar estratégias para galgar espaço no mundo esportivo, com a conquista de um número significativo de medalhas olímpicas. No entanto, de acordo com E2, a China só é capaz de vencer em "esportes novos", sem tradição olímpica, cuja prática não desperta interesse, tais como o levantamento de peso feminino, o taekwondo e o remo (sobretudo nas nações tradicionalmente bem sucedidas nos Jogos). Isso pode ser verificado no enunciado "O esporte [remo] é pouco praticado no mundo, então o nível internacional não é tão alto. É o oposto do que acontece com o futebol, onde o nível é altíssimo, então a China não consegue nada". A dupla negação "não consegue nada" reforça a condição de incompetência atribuída à China, numa vontade de verdade que vem construir a imagem negativa desse país.

A referência ao título da matéria pode ser percebida sob a rubrica "Complexo", numa indicação de que se trata de uma imagem imputada pelos próprios chineses. Em E2, no enunciado "Muitos chineses ainda se veem com o preconceito ocidental do século 19", observamos que o operador argumentativo "ainda" instaura um "agora" da enunciação que se reatualiza a cada leitura, de modo que o complexo de inferioridade é configurado como atual e constante, ou seja, é um sentimento que não acaba. Trata-se da articulação de um sentimento em que as construções verbais no tempo presente, "se veem" e "julgam-se", trazem o pronome reflexivo "se" para atribuir ao próprio chinês tal complexo, isentando as nações ocidentais.

Também, em E2, os adjetivos "menores, mais fracos e desnutridos" instauram uma contradição, uma comparação com o(s) outro(s) considerado(s) como maior(es), forte(s) e nutrido(s); aqui a representação identitária dos ocidentais é marcada por uma imagem positiva, forte e saudável, em detrimento dos traços identitários dos chineses, marcados por adjetivos que os desqualificam. Segundo a entrevistada, essa representação a que os chineses se imputam é decorrente de uma ideologia "desatualizada”, visto que o mundo ocidental "já [a] deixou para trás". Aqui, o operador argumentativo "já" permite ativar a rede de memória de que o Ocidente considerava os chineses inferiores, num passado não muito distante: havia, pois, uma ideologia colonialista que imputava ao país oriental uma imagem inferior, numa visão etnocêntrica, que procurava justificar a subjugação da China aos países ocidentais desenvolvidos. A mesma visão etnocêntrica tem tentado justificar o discurso colonial que, segundo Bhabha (2007, p. 11), tem por meta criar um estereótipo de degenerado para o colonizado, o que parece justificar a conquista e a imposição de um sistema administrativo colonizador. Embora essa visão ocidental em E2 se constitua como passado, instaurado pelo verbo no pretérito perfeito "deixou", os operadores argumentativos "mas" e "ainda" indicam uma ritualização do preconceito ocidental; visão também reforçada pelo verbo no presente do indicativo "deixa" em que, longe de ser um complexo sem justificativa, a marca colonialista continua latente.

Considerando as condições de produção desse discurso midiático, entendemos que a entrevista marca um regime de verdade que imprime uma visão estereotipada dos chineses, além disso, sendo a entrevistada uma pesquisadora, uma antropóloga e radicada 
em Pequim, suas palavras assumem a condição de verdade absoluta, pois ela o enuncia de seu lugar de autoridade, como estudiosa da sociedade humana. Entendemos ainda que, embora $\mathrm{E} 2$ venha mobilizar que o complexo de inferioridade seja algo imputado pelos chineses, esse discurso chega carregado de contradições, outros sentidos, como todo discurso, sujeito a falhas, ao equívoco próprio da linguagem: o Ocidente tem uma visão estereotipada e colonialista dos chineses, perspectiva que está longe de acabar. Portanto, mais do que complexo dos chineses, trata-se de preconceito contra os chineses, discurso estereotipado e cristalizado ao longo da história dessas nações. Nessa medida, vale considerar a tese de Rancière (1996) de que a política deve ter como base não o consenso, mas o conflito, efeito da angustiante presença da dissonância que o outro nos impõe; esse "outro" é o povo, sempre heteróclito, contraditório e multifacetado em seu desejo.

\section{(IN)CONCLUSÕES}

Com certeza, se é verdade que qualquer atividade humana possa ser cultura, ela não é necessariamente ou não é ainda forçosamente reconhecida como tal. Para que haja verdadeiramente cultura, não basta ser autor de práticas sociais; é preciso que essas práticas sociais tenham significado para aqueles que as realiza (DE CERTEAU)4.

Diante de nosso objetivo de problema-

$4 \quad$ Ver Michel de Certeau (1995, p. 141). tizar os discursos midiáticos, estudando os engendramentos do poder/saber desses discursos que trazem as marcas identitárias acerca da China, em determinado contexto social e histórico, homologamos que o discurso da Folha de S. Paulo confere à abertura dos Jogos Olímpicos de Pequim um caráter essencialmente político e evidencia a FD de onde o sujeito Folha enuncia seu discurso, qual seja, o capitalismo ocidental, marcado fortemente pelas ideologias das nações ocidentais, o que vem corroborar a construção de uma imagem negativa atribuída à China. Um país, segundo o discurso midiático, marcado pelo autoritarismo governamental, ausência de liberdade de informação e desconsideração com as minorias étnicas, evidenciando a marca identitária da desvalorização social e política, entre outras.

Examinamos que as relações de poder político e econômico ocidental determinam o surgimento desse discurso antichinês, visto que a Folha de S. Paulo, como quase todo órgão midiático brasileiro, insere-se na cultura e nos valores ocidentais e está sob a égide do poder econômico do imperialismo ocidental. Além disso, esse mass media é considerado como um veículo voltado à imagem de um público leitor escolarizado e com senso crítico aguçado, de modo que seus profissionais, cuja formação lhes garante conhecimento político e econômico, são capazes de perceber e de evidenciar o cunho político de um evento festivo como a abertura dos jogos olímpicos.

Homologamos também que o discurso da FSP marca uma vontade de verdade, que atribui à China uma imagem heterogênea, entre o autoritarismo, controle rigoroso da informação e ausência de direitos constitucionais básicos apregoados pelo Ocidente, 
e a imagem de subalternidade, de país periférico que busca superar a condição de colonizado. Essa imagem identitária que a FSP constrói da China não condiz com a condição de superpotência econômica que o país asiático tenta imprimir a si mesmo, assim, para a mídia brasileira, embora o país asiático tenha alcançado o posto de segunda economia do mundo, e seja importante parceiro comercial das nações desenvolvidas e em desenvolvimento, a China continua sendo marcado, identitariamente, como um país fechado aos valores ocidentais.

Por fim, é possível vislumbrar um caminho para se pensar uma política da diferença, e assumirmos, diante daqueles que pretendemos acolher em nossa nação, uma hospitalidade incondicional, o que significa oferecer-lhes uma hospedagem sem lhes impor pagamentos ou adaptações para que se acomodem ao tamanho do sofá que oferecemos.

\section{REFERÊNCIAS}

BBC BRASIL. Economia da China cresce $8,7 \%$ em 2009 e deve se tornar $2^{a}$ do mundo. Disponível em: <http://www.bbc.co.uk/ portuguese/noticias $>$. Acesso em: $20 \mathrm{abr} .2010$. BHABHA. H. O local da cultura. Trad. Myriam Ávila et. al. Belo Horizonte: UFMG, 2007.

CARDOTE, L. F. R. A crise econômica de 2008: a interdependência e as mudanças no regime financeiro internacional. Revista de direito da Unigranrio. Rio de Janeiro, v. 2, n. 2, 2009. CHARAUDEAU, P. Discurso das mídias. Trad. Ângela S. M. Corrêa. São Paulo: Contexto, 2009. CORACINI, M. R. F. A celebração do outro: arquivo, memória e identidade - línguas (materna e estrangeira), plurilinguismo e tradução. Campinas: Mercado de Letras, 2007.

DE CERTEAU, M. A Cultura no Plural. Trad. Enid A. Dobránszky. Campinas: Papirus,1995. DERRIDA, J. Anne Dufourmantelle convida Jaques Derrida a falar da Hospitalidade. Trad. Antonio Romane. São Paulo: Escuta, 2003.

FERREIRA, A. B. H. Dicionário do Aurélio. Disponívelem: $<$ http://www.dicionariodoaurelio. com>. Acesso em: 13 maio 2012.

FISH, S. Is there a text in this class? The authority of interpretative communites. [1980]. Trad. Rafael Eugenio Hoyos-Andrade. Alfa, São Paulo, n. 36, 1992.

Folha de S. Paulo, 06 de julho de 2008. Caderno Especial de Esporte.

FOUCAULT, M. A ordem do discurso. Trad. Laura Fraga de A. Sampaio. 16 ed. São Paulo: Loyala, 2008b.

Arqueologia do saber. Trad. Luiz Felipe B. Neves. 7 ed. Rio de Janeiro: Forense Universitária, 2008a.

Method. The history of sexuality: an introduction. v. 1. Vintage, 1990 [1976].

Microfísica do poder. Trad. Roberto Machado. 24 ed. Rio de Janeiro: Edições Graal, 2009.

Vigiar e punir: o nascimento da prisão. Trad. Raquel Ramalhete, 24 ed. São Paulo: Vozes, 2001.

GUERRA, V M. L.; BENITES, F. R. G. Movimentos interpretativos em Nietsche, Foucault, Fish e Derrida. In: GUERRA, V. M. L; NOLASCO; E. C. (Orgs.). Formas, espaços, tempos: reflexões linguísticas e literárias. Campo Grande: UFMS, 2010.

GUERRA, V. M. L. O indígena de Mato Grosso do Sul: práticas identitárias e culturais. São Carlos: Pedro e João editores, 2010.

GREGOLIN, M. do R. V. Análise do discurso e mídia: a (re)produção de identidades - 
comunicação, mídia e consumo. Revista da ESPM. São Paulo, v. 4, n 11, nov. 2007.

. (Org.). Discurso e mídia: a cultura do espetáculo. São Carlos: Claraluz, 2003.

HENRY, P. A história não existe? In: ORLANDI, E. P. (Org). Gestos de leitura. Campinas: Editora da Unicamp, 1994.

JAMESON, F. A cultura do dinheiro: ensaio sobre a globalização. Trad. Maria Elisa Cevasco e Marcos P. Santos. Petrópolis: Vozes, 2001.

LACAN, J. A função e o campo da fala e da linguagem em Psicanálise. 3 ed. In: Escritos. São Paulo: Perspectiva, 1988.

LE BOT, M. Le silence dans les mots. In LE BOT, Marc. Corps Ecrit. Paris: PUF, 1984.

NAVARRO-BARBOSA, P. O papel da imagem e da memória na escrita jornalística da história do tempo presente. In: GREGOLIN,
M. R. (Org.). Discurso e mídia: a cultura do espetáculo. São Carlos: Claraluz, 2003.

NIETZSCHE, F. Verdade e mentira no sentido extramoral. In Revista Comum, Rio de Janeiro, v. 6 n. 17, jul/dez 2001. Extraído de Oeuvre Philosophiques Completes, I,II, Écrits Posthumes: 1870-1873, Paris: Gallimard, 1975. ORLANDI, E. P. Interpretação: autoria, leitura e efeitos do trabalho simbólico. Petrópolis: Vozes, 1996.

PÊCHEUX, M. Semântica de discurso: uma crítica à afirmação do óbvio. Trad. Eni Orlandi et. al. 4 ed. Campinas: Editora da Unicamp, 2009.

RANCIÈRE, J. O desentendimento. Trad. Ângela Leite Lopes. São Paulo: 34, 1996.

TREVISAN, C. China: o renascimento do império. São Paulo: Planeta do Brasil, 2006.

Recebido para publicação em 27 ago. 2013. Aceito para publicação em 09 jan. 2014. 